\title{
SUPPLY CHAIN MANAGEMENT AND ITS PRACTICAL IMPACT
}

\author{
Shreyansh Jain \\ Symbiosis institute of business management (SIBM) Symbiosis international (Deemed university)(SIU), Electronic City, Hosur \\ Road, Bengaluru, Karnataka, India \\ E-mail: shreyansh.jain21@sibm.edu.in
}

\begin{abstract}
This paper studied about the role of different independent factors on supply chain responsiveness. Here, we considered factors such as joint decision making, information quality and performance risk as three independent variables and supply chain responsiveness as a dependent variable. We tried to survey different supply chain professionals working in different sectors to have an unbiased image in our study.

After applying Pearson corelation in our study, we understood the significance of our independent variables on supply chain responsiveness. The positive significance shows the importance of these factors while working on our dependent variable. All three relationships are showcasing either positive or strong corelation. Finally, we could infer that there are a lot more factors that we can take in to consideration for calculating the impact on supply chain responsiveness in future studies. This will definitely strengthen the case and will help in practical explanation.
\end{abstract}

Keywords: Supply chain responsiveness, Joint decision making, Information Quality, Performance Risk, Pearson Corelation(1 tail).

\section{Introduction}

Supply chain Management underlines the maximization of the total value of the organisation while utilizing and implementing the chain of resources to the whole company .Through a supply chain we can add value to the product while connecting the customers and suppliers in an end to end chain. The supply chain activities involves getting the inbound from the suppliers and add value to it to deliver it to your customers. The chain of supply chain involves manufacturer, suppliers, retailers, warehouses, transporters and customers. All these segments are involved directly or indirectly with the common goal of fulfilling the customer demand. Just like in manufacturing, supply chain also involves all the functions starting from receiving to fulfilling the customer's request. All the functions are Marketing, distribution, customer service, new product development, operation etc. When we talk about the performance factor, it is always helpful to integrate and manage the information flow in to the supply chain. An effective SCM is always a plus point and works as a competitive advantage in fulfilling customer demand. It is always beneficial to integrate your infrastructure, according to current technology trends. Information technology impact the supply chain effectiveness, integrating in to these technologies will impact various other functions of supply chain management such as, flexibility, delivery, cost, quality and hence forth profit. Developing your infrastructure while using IT will also help in a better ROI and will help in diversification to increase market share. Business strategies always need the support of main functions such as SCM

Procurement, Logistics, Marketing, Finance to achieve the competitive advantage. Integration to IT will definitely help in coordination with Business strategies, which directly reciprocates to the organisations financial performance.

Incrementation in global competition, employees and Customers demand, decreament in acceptable response times and shrinking product life cycles are faced by the organizations in recent times. Competition has a new companion dependent on capabilities or we can say that "complex bundles of accumulated knowledge and skills, exercised through organisational process". Strategic assets such as brand equity, investment in scale and scope plus implementing your assets while competing these days. Companies are now moving towards integrating their processes and not just a collection of functional areas. It has become normal for companies to organize or form competitive networks outside their legal boundaries. Organizations have developed strategically aligned capabilities outside its company to the networks which tends to add value as well. This has led to firms implementing new strategic assets in their business process. As they mature it has been observed that there will be a requirement of development and investment. With a result in process maturity, organisations do have an adoption of process view. When we talk about process lifecycle, it occurs in developmental stages. It has been observed through our limit, on behalf of the procedure which is thoroughly measured, defined, controlled and managed. It 
meant development in the areas of consistency and richness, process capability through the whole firm

2. Literature Review:

\begin{tabular}{|l|l|}
\hline AUTHORS & Definitions \\
\hline Dias et al. & $\begin{array}{l}\text { SCM is the errand of incorporating } \\
\text { hierarchical units along a gracefully } \\
\text { chain and organizing materials, data } \\
\text { and budgetary streams to satisfy } \\
\text { client requests to improve the } \\
\text { intensity of the flexibly chain } \\
\text { overall. }\end{array}$ \\
\hline $\begin{array}{l}\text { Wibowo et } \\
\text { al. (2017) }\end{array}$ & $\begin{array}{l}\text { "Supply Chain Management is the } \\
\text { key business measures from end- } \\
\text { client through unique providers that } \\
\text { gives items, administrations, and } \\
\text { data that add an incentive for the } \\
\text { client and different partners". }\end{array}$ \\
\hline $\begin{array}{l}\text { Skojett- } \\
\text { Larsen } \\
\text { (1999) }\end{array}$ & $\begin{array}{l}\text { SCM is observed through numerous } \\
\text { points of view, for example, } \\
\text { framework designing, financial } \\
\text { aspects, human science and the } \\
\text { executives. }\end{array}$ \\
\hline
\end{tabular}

Dubey et al. SCM, an idea deals with the (2012) progression of material, data and assets start to finish for example goes from manufacturing to selling individuals. This likewise manages removal in components in later utilization according to natural standards. SCM attempts to accomplish this at the most minimal expense with greatest proficiency.

Kain et al. "Supply Chain is characterized as an (2018) arrangement of associations, individuals, exercises, data, and assets engaged with moving an item or administration from provider to client. Supply chain exercises include the change of characteristic assets, crude

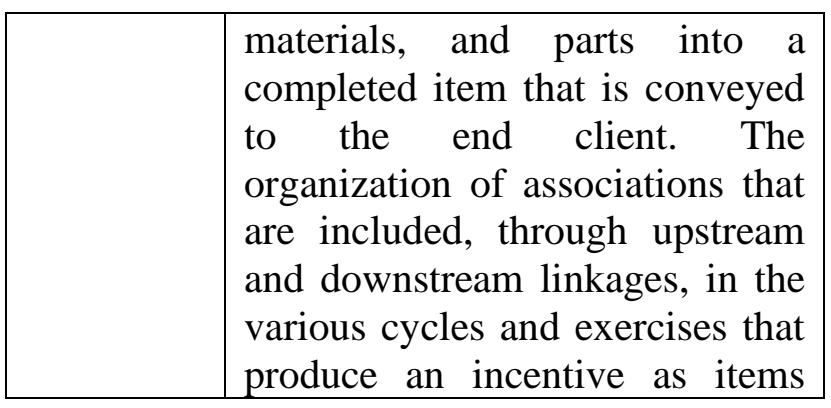

\begin{tabular}{|c|c|}
\hline & $\begin{array}{l}\text { and administrations conveyed to } \\
\text { a definitive buyer". }\end{array}$ \\
\hline $\begin{array}{l}\text { Walton } \\
\text { and } \\
\text { Gupta } \\
\text { (1999) }\end{array}$ & $\begin{array}{l}\text { SCM the board, reconciliation } \\
\text { along different ideas, for } \\
\text { example, broadened endeavour, } \\
\text { the virtual association, the virtual } \\
\text { worth chain as well as green } \\
\text { gracefully chain. The viewpoints } \\
\text { are significant with some } \\
\text { viewpoint of system and tasks on } \\
\text { an organisation or industry. }\end{array}$ \\
\hline $\begin{array}{l}\text { Harjeet et } \\
\text { al. }(2016)\end{array}$ & $\begin{array}{l}\text { "Supply chain the board is } \\
\text { basically the administration of } \\
\text { transport or stream of } \\
\text { merchandise and ventures, it } \\
\text { additionally incorporates } \\
\text { capacity, timeframe of realistic } \\
\text { usability, investigation of } \\
\text { products obtained and products } \\
\text { sold coordination's, and so on } \\
\text { Flexibly chain the executives } \\
\text { helps in arranging and executing } \\
\text { different gracefully chain } \\
\text { exercises of a specific association } \\
\text { to develop a net estimation of the } \\
\text { association, deciding the current } \\
\text { market pattern identified with the } \\
\text { interest and gracefully of any } \\
\text { products or administrations and } \\
\text { synchronizing the equivalent for } \\
\text { estimating the presentation of the } \\
\text { association". }\end{array}$ \\
\hline $\begin{array}{l}\text { McCorma } \\
\text { ck }\end{array}$ & $\begin{array}{l}\text { SCM includes measures that } \\
\text { takes companies abilities on } \\
\text { synchronizing tasks to } \\
\text { incorporate originator, and } \\
\text { convey measures with a joint } \\
\text { effort through something which } \\
\text { accomplices. }\end{array}$ \\
\hline $\begin{array}{l}\text { Harland } \\
\text { (1996) }\end{array}$ & $\begin{array}{l}\text { Supply chain the board } \\
\text { coordinates two business } \\
\text { capacities, it oversees close } \\
\text { associations with providers, and } \\
\text { it likewise incorporates chain of } \\
\text { provider's providers and a client's } \\
\text { clients, etc. It belongs to the } \\
\text { interconnection of businesses }\end{array}$ \\
\hline
\end{tabular}




\begin{tabular}{|c|c|}
\hline & $\begin{array}{l}\text { with administration that is } \\
\text { attached in a definitive cycle of } \\
\text { items with the necessity of } \\
\text { bundles in administration. }\end{array}$ \\
\hline $\begin{array}{l}\text { Ellram et } \\
\text { al. (2019) }\end{array}$ & $\begin{array}{l}\text { "SCM chain the executives that } \\
\text { incorporates the arranging and } \\
\text { the board of all exercises } \\
\text { engaged with sourcing and } \\
\text { acquisition, transformation, and } \\
\text { all coordination's the board } \\
\text { exercises. Critically, it likewise } \\
\text { incorporates coordination and } \\
\text { cooperation with channel } \\
\text { accomplices, which can be } \\
\text { providers, mediators, outsider } \\
\text { specialist organizations, and } \\
\text { clients.". }\end{array}$ \\
\hline $\begin{array}{l}\text { Melnyk et } \\
\text { al. (2009) }\end{array}$ & $\begin{array}{l}\text { "SCM is essentially liable for } \\
\text { dealing with the purchasing just } \\
\text { as dealing with the progression } \\
\text { of requests and data" is not, at } \\
\text { this point legitimate. Today all } \\
\text { the connected viewpoints, for } \\
\text { example, improving client } \\
\text { support, relieving flexibly chain } \\
\text { hazard, diminishing squanders, } \\
\text { improving new item } \\
\text { configuration measure and } \\
\text { upgrading item administration } \\
\text { quality are treated as a vital } \\
\text { portion of SCM. }\end{array}$ \\
\hline
\end{tabular}

\begin{tabular}{|l|l|}
\hline $\begin{array}{l}\text { Martins et } \\
\text { al. (2019) }\end{array}$ & $\begin{array}{l}\text { "The way toward arranging, } \\
\text { executing and controlling the } \\
\text { activities of the gracefully affix } \\
\text { with the reason to fulfil client } \\
\text { necessities as proficiently as } \\
\text { could reasonably be expected. } \\
\text { SCM executives traverses all } \\
\text { development and capacity of } \\
\text { crude materials, work-in- measure } \\
\text { stock, and completed } \\
\text { merchandise from purpose of- } \\
\text { beginning to purpose of- } \\
\text { utilization". }\end{array}$ \\
\hline Chen & $\begin{array}{l}\text { SCM simply manages the vital } \\
\text { choices, for example, between } \\
\text { hierarchical issues, elective }\end{array}$ \\
\hline
\end{tabular}

\begin{tabular}{|c|l|}
\hline $\begin{array}{l}\text { aulraj } \\
\text { (2004) }\end{array}$ & $\begin{array}{l}\text { authoritative structure to vertical } \\
\text { reconciliation. It is additionally } \\
\text { the administration of connection } \\
\text { among providers and clients. }\end{array}$ \\
\hline Desai e & $\begin{array}{l}\text { "SCM is characterized as the } \\
\text { incorporation of key business } \\
\text { measures from end clients } \\
\text { through unique providers that } \\
\text { give items, administrations and } \\
\text { data which enhance clients and } \\
\text { different partners". }\end{array}$ \\
\hline
\end{tabular}

The discourse of SCM discipline is very broad considering its theoretical and methodological scope, while BSCM is a small niche in contrast with relevance to man behaviour for its SCM conditions. That confirms the importance of addressing the term integration in the field of SCM. There is a contention that expands on association speculations to respond to questions: how to structure the supply chain and how to deal with a specific structure and proposed that this can be viewed as an endeavour to reduce the hole between ebb and flow SCM examination and practice and existing hypothetical clear and prescriptive clarifications, this corelates to the diffusion of supplier innovativeness o the supply chain. This model explains importance of examination in SCM with supplier innovativeness relationship. Few of the examples includes strategic sourcing from buyers and information sharing. This captures the impact of supplier innovativeness on SCM effectiveness.

\section{Information quality}

Supply Chain Practice can be attained, when IQ can be maintained. Whenever a firm needs to achieve overall business performance, alignment with Information Quality and SCP is needed. Delivery practice and Sourcing practice are some of the supply chain practices which are under investigation. Just having customer forecasts will not be suffice. The quality of information is required in the interpretation and possible use of forecasted data. The measurement of Information quality has to be judged by the receiving supplier and not objectively. Information gathered has to be Concise, accurate and timely. There are various possible ways to measure information quality such as: adequacy, completeness, accuracy, timeliness and reliability. The equation of FIQ is not measured as the deviation between forecast and actual demand but expressed as mean error or mean absolute deviation. FIQ is discussed further as well. Some of the features of FIQ are critical. More exactly, no study of measurement of FIQ was found, general studies are there with some information quality studies 


\section{Joint decision making}

Collaboration can be between departments and people as well as between organisations. For example, cases that signifies those points which enables while undertaking the development of logistics, procurement and operations. Decentralized retailers are not preferred by suppliers in real management practices. More market information is always with the retailers as they directly deal with customers. Retailers always have an upper hand over suppliers on this data and they use it to bargain from suppliers. The deciding factor is which end these strategies favour to, the supplier or the retailer. A framework has been developed called as "arcs of integration" which clarifies the extensive customer integration to extensive supplier integration.

\section{Performance risk}

Most fields of management control and decision will have risk management as an emerging and important contributor. Sharing of information involves willingness of exchange possible proprietary or partners. To support integration and having collaborative association in information sharing of SCM data is needed. Reasons why companies are turning towards risk management are technological change, global competition and competitive advantage. Supplier management tools are required to take risks as risk and performance are interconnected and asks for robust implementation. Significance of information sharing has also been mentioned by some of the Japanese companies.

\section{Supply chain responsiveness}

Any organisation needs to have customer responsiveness to gain any kind of competitive advantage. Customer needs and wants also need to have responsiveness at most priority. The frameworks of any supply chain for an organisation is generally different from its literature. The relationship of supply chain responsiveness and its strategy has to be controlled by appropriate supply chain practices. When we talk about lean supply chain, it pertains to reducing costs by implementing continuous improvement techniques and inventory management through its chain. The SCM with its capabilities of adjusting capacity, reduction in set-up time by responding to the customer quickly. Agility is also an important factor in supply chain responsiveness.

\section{Research Framework}

After the extensive literature review, we have formulated a framework. In the figure shown below, we have information quality, joint decision making, performance risk as independent variables and one dependent variable i.e supply chain responsiveness. Responsiveness spectrum and Efficient supply chain are two other factors that are interrelated to all the independent variables

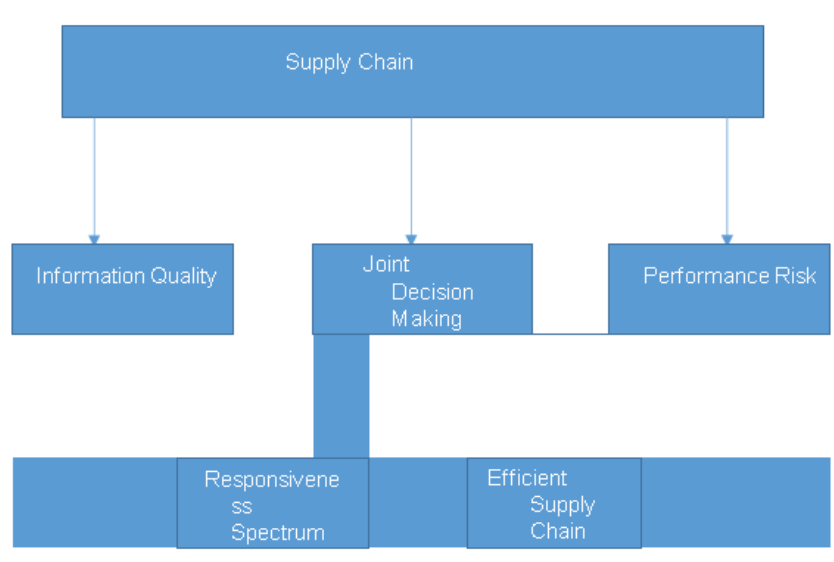

\section{Problem statement:}

Due to the advancement in technology in the supply chain domain, factors such as Information quality, Joint decision making and performance risk becomes evident to identify the level of supply chain responsiveness. Organizations are not the only one effected from any kind of disruption, the whole industry is affected. Advancements in this sector is on a verge of transformation with supply chain responsiveness becoming main competent area. Our objective in this research is to find out some factors that affect SCM responsiveness.

\section{Objective:}

Our objective is to have a look in to various factors which has an impact on supply chain responsiveness. How much is the impact and its significance? How these factors affect our dependent variable which will help supply chain professionals in future to have an efficient supply chain. The interdependency will help in better supply chain operations.

\section{Methodology:}

Our aim depends on the identification in dependence of SCM responsiveness on the basis of certain factors. The study we've done is an empirical study in which a survey has been done. Individuals with relevant work experience were approached for this survey. Supply chain responsiveness has been an integral part of any operations for a product based company as it directly provides value to the customers. Globally many researches have already been done on this, and many companies have integrated this in their supply chain management. We have surveyed through questionnaires after the literature review. This questionnaire corresponds to various studies done previously to have a standard match of previous studies. We have used

Likert scale as a method to collect responses and collected them through Google forms. Following table describes the references and sub dimensions of our dependent and independent variables 


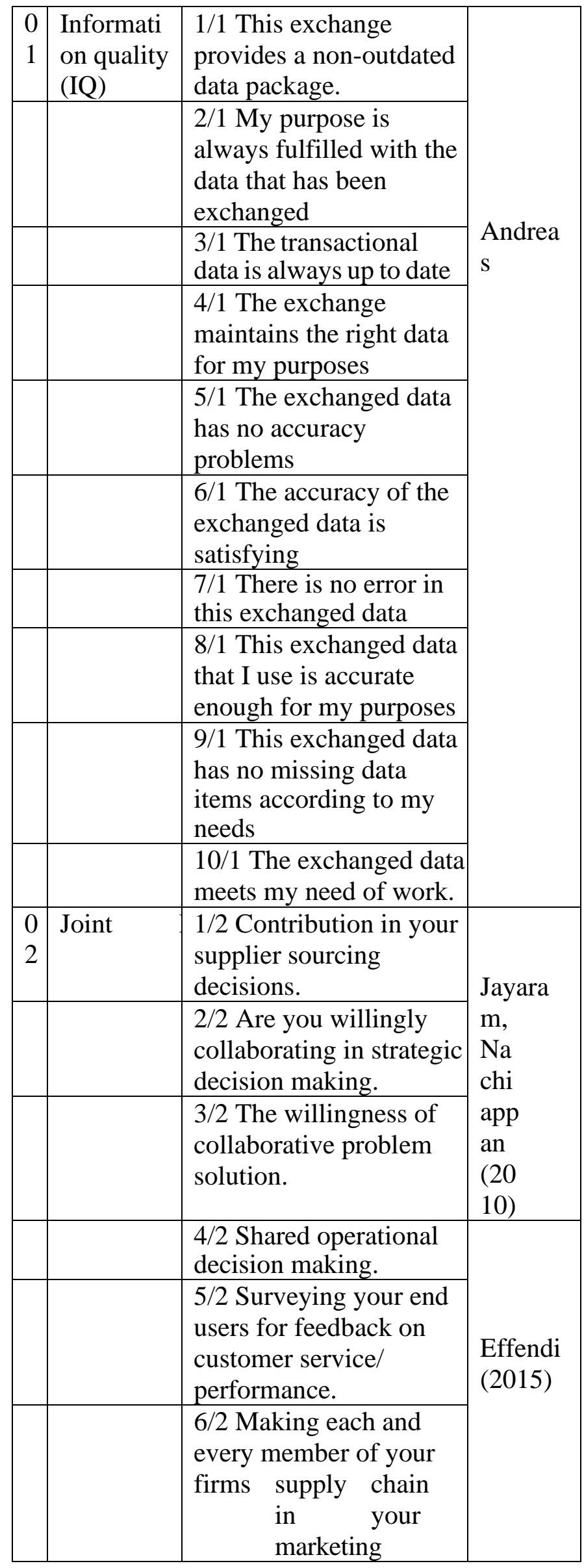

\section{Data statistics:}

Our target segments are mid-level executives with significant experience in supply chain management. Information quality, Performance risk and Joint decision making are variables in independent relation and dependent factor is Supply chain

\begin{tabular}{|l|l|l|}
\hline & & plans/service/product. \\
\hline 0 & $\begin{array}{l}\text { Performan } \\
\text { in the marketing efforts } \\
\text { of your customers. }\end{array}$ & \\
\hline & $\begin{array}{l}1 / 3 \text { Vendor not operating } \\
\text { well is a risk }\end{array}$ & \\
\hline & $\begin{array}{l}\text { 2/3 The ability to } \\
\text { perform as expected by } \\
\text { vendor is a Risk }\end{array}$ & Andrea \\
& $\begin{array}{l}\text { 3/3 Risk of vendor not } \\
\text { producing the required } \\
\text { products }\end{array}$ \\
\hline $\begin{array}{l}4 / 3 \text { Risk of vendor not } \\
\text { having the required } \\
\text { knowledge to execute } \\
\text { the order. }\end{array}$ \\
\hline $\begin{array}{l}5 / 3 \text { The vendor is } \\
\text { committed to } \\
\text { accomplish } \\
\text { the goals of the } \\
\text { relationship }\end{array}$ \\
\hline $\begin{array}{l}\text { 6/3 The goals of the } \\
\text { relationship has to be } \\
\text { accomplished by the } \\
\text { vendor }\end{array}$ \\
\hline
\end{tabular}

\begin{tabular}{|c|c|c|c|}
\hline & & $\begin{array}{l}\text { 7/3 Risk of vendor facing } \\
\text { performance problems }\end{array}$ & \\
\hline $\begin{array}{l}0 \\
4\end{array}$ & Supply & $\begin{array}{l}\text { 1/4 Management of } \\
\text { distant facilities }\end{array}$ & \multirow{5}{*}{$\begin{array}{l}\text { Tec } \\
\text { k-Y } \\
\text { ong } \\
\text { En } \\
\mathrm{g} ; 2 \\
005\end{array}$} \\
\hline & & 2/4 Track shipments & \\
\hline & & $\begin{array}{l}3 / 4 \text { Reduce the level of } \\
\text { paperwork in a supply } \\
\text { chain system. }\end{array}$ & \\
\hline & & $\begin{array}{l}4 / 4 . \\
\text { product/service concept } \\
\text { to introduction we need } \\
\text { to achieve or maintain } \\
\text { responsiveness. }\end{array}$ & \\
\hline & & $\begin{array}{ll}5 / 4 & \text { Develop } \\
& \text { innovative } \\
& \text { new } \\
\text { products/services }\end{array}$ & \\
\hline
\end{tabular}


responsiveness. We have surveyed supply chain professionals from the industries like E-commerce, Cold chain logistics, FMCG, Healthcare etc. We collected the data through surveying with Questionnaire method. Response collection were through Google forms and emails. Sample size was 178 due to economic constraints and paucity of time. Majority of respondents have an experience of 8 years in their respective fields. Data has been collected specifically for each factor.

\section{Analysis:}

SPSS 23 version was used for data analysis. Manual screen of data has been performed after the analysis of first special codes with high mission value responses alongside omission of same kind of responses. Going forward data cleaning and omission of outliers is done through skewness and kurtosis method, histogram and Q-Q plot. In addition, Cronbach's o have been used for data reliability. The given information in tabular format signifies the value of standard deviation and mean of Cronbach's o. Factors like information quality have the mean value which is highest on 3.345 , Joint decisionmaking mean is 3.845 , performance risk mean is

4.051 and about the dependent variable i.e supply chain responsiveness, the mean is 4.512. To find the relationship among variables, we have tested for one tail Pearson Correlation. This has helped us in determining the relationship between all the independent variables and supply chain responsiveness. All three relationships with the dependent variables are significant according to our Analysis. The corelation between information quality and supply chain responsiveness is $0.698^{* *}$, which dictates the significance of the relationship. The value of corelation for joint decision making is $0.5^{* *}$, which again is positive. The value of corelation among the members of performance risk is $0.567^{* *}$, which is a significant relationship as well. All three relationships are showcasing either positive or strong corelation

\begin{tabular}{|l|l|l|l|}
\hline Factor & $\begin{array}{l}\text { Value of } \\
\text { Cronbach's o }\end{array}$ & Value of SD & $\begin{array}{l}\text { Value of } \\
\text { Mean }\end{array}$ \\
\hline IQ & .842 & .50843 & 4.1819 \\
\hline JDM & .761 & .53671 & 4.0124 \\
\hline
\end{tabular}

\begin{tabular}{|l|l|l|l|}
\hline PR & .764 & .89024 & 3.0218 \\
\hline SCR & .687 & .58371 & 3.8961 \\
\hline
\end{tabular}

\begin{tabular}{|l|l|l|l|l|}
\hline $\begin{array}{l}\text { Fac } \\
\text { tor }\end{array}$ & $\begin{array}{l}\text { Info. } \\
\text { Quality }\end{array}$ & $\begin{array}{l}\text { Jt. Decision } \\
\text { making }\end{array}$ & $\begin{array}{l}\text { Performance } \\
\text { Risk }\end{array}$ & SCR \\
\hline IQ & 1 & & & \\
\hline JD & .109 & 1 & & \\
M & & & & \\
\hline PR & $.412^{* *}$ & $.502^{* *}$ & 1 & \\
\hline $\begin{array}{l}\text { SC } \\
\text { R }\end{array}$ & $.698^{* *}$ & $.5^{* *}$ & $.567 * *$ & 1 \\
\hline
\end{tabular}

$* *$ Corelation at the 0.01 level is significant ( 1 tailed) *Corelation at the 0.05 level is significant (1 tailed)

\begin{tabular}{|c|c|c|c|c|c|c|c|}
\hline \multirow[t]{2}{*}{$\begin{array}{l}\text { Mode } \\
1\end{array}$} & \multicolumn{2}{|c|}{$\begin{array}{l}\text { Coefficie } \\
\text { nts which } \\
\text { are } \\
\text { standardis } \\
\text { ed }\end{array}$} & $\begin{array}{l}\text { Stan } \\
\text { dard } \\
\text { ized } \\
\text { Coef } \\
\text { ficie }\end{array}$ & \multirow{2}{*}{$\begin{array}{l}\mathrm{Va} \\
\text { lue } \\
\text { of } \\
\mathrm{R}^{\wedge} \\
2\end{array}$} & \multirow[t]{2}{*}{$\begin{array}{l}\mathrm{V} \\
\text { al } \\
\mathrm{u} \\
\mathrm{e} \\
\text { of } \\
\mathrm{Si} \\
\mathrm{g} .\end{array}$} & \multirow[t]{2}{*}{$\begin{array}{l}\text { Valu } \\
\text { e of } t\end{array}$} & \multirow[t]{2}{*}{$\begin{array}{l}\text { Remark } \\
\mathrm{s}\end{array}$} \\
\hline & B & $\begin{array}{l}\text { Std. } \\
\text { Error }\end{array}$ & $\begin{array}{l}\text { Value } \\
\text { of Beta }\end{array}$ & & & & \\
\hline $\begin{array}{l}\text { Valu } \\
\text { e of a }\end{array}$ & $\begin{array}{l}1.2 \\
38\end{array}$ & .321 & & & $\begin{array}{l}4.1 \\
85\end{array}$ & .000 & \\
\hline IQ & $\begin{array}{l}.62 \\
7\end{array}$ & .072 & .161 & $\begin{array}{l}.56 \\
0\end{array}$ & $\begin{array}{l}2.2 \\
76\end{array}$ & .000 & $\begin{array}{l}\text { Support } \\
\text { ed }\end{array}$ \\
\hline JDM & $\begin{array}{l}.54 \\
1\end{array}$ & .071 & .382 & $\begin{array}{l}.50 \\
9\end{array}$ & $\begin{array}{l}5.4 \\
82\end{array}$ & .000 & $\begin{array}{l}\text { Support } \\
\text { ed }\end{array}$ \\
\hline PR & $\begin{array}{l}.61 \\
9\end{array}$ & .039 & -.002 & $\begin{array}{l}.38 \\
4\end{array}$ & $\begin{array}{l}- \\
.04 \\
8\end{array}$ & .000 & $\begin{array}{l}\text { Not } \\
\text { Support } \\
\text { ed }\end{array}$ \\
\hline
\end{tabular}

a. Dependent variable: Supply chain responsiveness

IQ: Information Quality JDM: Joint Decision Making PR: Performance Risk

SCR: Supply Chain Responsiveness

While testing the assumptions of homoscedasticity, linearity, residual independency, and normality, normal distribution of residuals, multiple regression confirmed the synopsis. It also helps us determining the research variables direction towards being linear and the degree of strength. The above table of regression analysis shows the relationship between dependent variable and independent variable. All three independent variables were regressed against supply chain responsiveness with a variance of, $\mathrm{R}^{\wedge} 2(.560), \mathrm{R}^{\wedge} 2(.509), \mathrm{R}^{\wedge} 2(.384)$, respectively which indicates that $56 \%$ of Information Quality, $50.9 \%$ of joint decision making and $38.4 \%$ can increase the effect of SC responsiveness within the industry. Models which relate the independent and dependent variables was developed using multiple regression analysis. Supply chain responsiveness which is the dependent variable in our first model, have $\mathrm{p}$-value

$<0.01$ whearas for 0.05 independent variables it is $<0.05$.

Information Quality and other independent variables explains that variance ( $\mathrm{r} 2)$ of SCM in the results. This individual prediction contribution in the model is indicated by Beta coefficient values. Information quality has a beta value of .627 , this mean the overall impact of Information quality on SCR with one unit of increase is 0.627. Similarly, Supply chain responsiveness and joint decision making has a significance of .541. Similarly, with one unit increase in Performance risk there would be an impact of .619 on supply chain responsiveness. The relationship of supply chain 
responsiveness is significant with Information quality and Joint

decision making but not significant with performance risk, so we accept $\mathrm{H} 1$ and $\mathrm{H} 2$ but $\mathrm{H} 3$ is not accepted.

\section{Limitations:}

There were certain limitations with our research which are as follows:

- The responses were limited.

- We couldn't approach supply chain professionals in every industry.

- Couldn't include a senior level perspective in the research.

- This method is unidirectional.

- There could be other factors as well, which affects the supply chain responsiveness.

\section{Conclusion:}

This research take three independent variables and one dependent variables in to consideration. Three independent variables are Joint Decision Making, Information Quality and Performance Risk. The dependent variable and the factor we are trying to test here is supply chain responsiveness. All the three independent factors influence Supply chain responsiveness positively, with all the relevance from supply chain literature. This study suggests the importance of supply chain responsiveness and its influence on supply chain professionals on a measured scale. This research is conducted to understand the relationship between certain supply chain parameters and its responsiveness. The current study also includes the methods to enhance the supply chain responsiveness literature. Except Performance risk all the other independent variables has a significant impact. In this process it represents a theoretical perspective of supply chain management's potential deployment as a means to achieve supply chain responsiveness. In a holistic perspective, this research provides further development in the relationships of Supply chain responsiveness and its performance, which depends on certain factors and the exact impact measurements. There are a lot of researches that has happened on certain other methods to enhance supply chain responsiveness, in future a comparative study should be conducted between these researches

\section{References}

[1] Jharkharia.S. \& Shukla.M. (2013), "Agri-fresh produce supply chain management: a state-of-theart literature review", International Journal of Operations \&Production Management Vol. 33 No. 2, pp. $114-158$

[2] Machowiak, W. (2012). Risk managementunappreciated instrument of supply chain management strategy. LogForum, 8(4), pp. 277285.

[3] Melnyk, S. A., Lummus, R. R., Vokurka, R. J., Burns, L. J., \& Sandor, J. (2009). Mapping the future of supply chain management: a Delphi study. International Journal of Production Research, 47(16), pp. 4629-4653.

[4] Lavastre, O., Gunasekaran, A., and Spalanzani, A. (2012), "Supply chain risk 828-838

[5] Lin,L.C.(2009), "An integrated framework for the development of radio frequency identification technology in the logistics and supply chain

[6] Miles, E.R. and Snow, C.C. (2007), "Organization theory and supply chain Management, Vol. 25, No. 2 pp. 459 - 463.

[7] Nguyen, T.U.H, (2007), "Strategies for successful CRM implementation", Information Management and Computer Security, Volume 15, No. 2, 2007, pp. 102-115

[8] Parkan, C., \& Dubey, R. (2009). Recent developments in the practice of supply chain management and logistics In India. Portuguese Journal of Management Studies, 14(1), pp. 71-88.

[9] Petroni, A. (2002), "Critical factors of MRP implementation in small and Management, Vol. 22, No. 3, pp. 329-348

[10] Rahman, Z. (2003), "Internet-based supply chain management: using the Management, Volume 23, pp. 493-505.

[11] Randall, W. S., \& Mello, J. E. (2012). Grounded theory: an inductive method for supply chain research. International Journal of Physical Distribution \& Logistics Management, 42(8/9), pp. 863-880.

[12] Rexhausen, D., Pibernik, R.and,Kaiser, G .(2012), "Customer-facing supply chain practices -The impact of demand and distribution management on supply chain success", Journal of Operations Management, Volume 30, pp. 269-281

[13] Sachan, A., \& Datta, S. (2005). Review of supply chain management and logistics research. International Journal of Physical Distribution \& Logistics Management, 35(9), pp. 664-705

[14] Vachon, S., \& Klassen, R. D. (2007). Supply chain management and environmental technologies: the role of integration. International Journal of

[15] Production Research, 45(2), 401-423.

[16] Wadhwa, S., Saxena, A., \& Chan, F. T. S. (2008). Framework for flexibility in dynamic supply chain management. International Journal of Production Research, 46(6), 1373-1404.

[17] Williamson, O. E. (2007). The Economic Institutions of Capitalism. Firms, Markets, Relational 
Contracting. In Das Summa Summarum des Management (pp. 61-75). Gabler.

[18] S. Chopra, P. Meindl

[19] Supply Chain Management: Strategy, Planning \& Operation. (3th ed) Prentice-Hall. Inc, NJ (2007)

[20] S. Cohen, J. Roussel

[21] Strategic Supply Chain Management: The Five Disciplines for Top Performance McGraw-Hil, New York (2005)

[22] K.W. Green Jr., D. Whitten, R.A. Inman

[23] The impact of logistics performance on organizational performance in a supply chain context Supply Chain Management, 13 (4) (2008), pp. 317-327

[24] A. Gunasekaran, E.W.T. Ngai

[25] Information systems in supply chain integration \& management European Journal of Operational Research, 159 (2) (2004), pp. 269-295

[26] S.C. Koh, M. Demirbag, E. Bayraktar, E. Tatoglu, S. Zaim

[27] The impact of supply chain management practices on performance of SMEs Industrial Management and Data Systems, 107 (1) (2007), pp. 103-124

[28] S. Li, B. Ragu-Nathan, T.S. Ragu-Nathan, S.S. Rao

[29] The impact of supply chain management practices on competitive advantage and organizational performance

[30] Omega, 34 (2) (2006), pp. 107-124

[31] S. Li, S.S. Rao, T.S. Ragu-Nathan, B. Ragu-Nathan

[32] Development and validation of a measurement instrument for studying supply chain management practices

[33] Journal of Operations Management, 23 (6) (2005), pp. 618-641

[34] S. Li, B. Lin

[35] Accessing information sharing and information quality in supply chain management Decision Support Systems, 42 (3) (2006), pp. 641-1656
[36] C.R. Moberg, B.D. Cutler, A. Gross, T.W. Speh

[37] Identifying antecedents of information exchange within supply chains

[38] International Journal of Physical Distribution and Logistics Management, 32 (9) (2002), pp. 755-770

[39] D. Towill, M. Christopher

[40] The supply chain strategy conundrum: To be lean or agile or to be lean $\&$ agile?

[41] International Journal of Logistics: Research \& Applications, 5 (3) (2002), pp. 299-309

[42] S.K. Vickery, J. Jayaram, C. Droge, R. Calantone

[43] The effects of an integrative supply chain strategy on customer service and financial performance: an analysis of direct versus indirect relationships

[44] Journal of Operations Management, 21 (5) (2003), pp. 523-539

[45] M.A. Vonderembse, M. Uppal, S.H. Huang, J.P. Dismukes Designing supply chains: Towards theory development

[46] International Journal of Production Economics, 100 (2) (2006), pp. 223-238

[47] J.D. Wisner

[48] A structural equation model of supply chain management strategies and firm performance Journal of Business Logistics, 24 (1) (2003), pp. 126

[49] C.Y. Wong, J.S. Arlbjorn, J. Johansen

[50] Supply chain management practices in toy supply chains

[51] Supply Chain Management: An International Journal, 10 (5) (2005), pp. 367-378

[52] H. Zhou, W.C. Benton

[53] Supply chain practice and information sh777aring

[54] Journal of Operations Management, 25 (6) (2007), pp. $1348-1365$. 